\title{
THE IDENTIFICATION OF PERSUASIVE MESSAGE CAMPAIGN “WONDERFUL INDONESIA 2015"
}

\author{
Ilona Vicenovie Oisina Situmeang ${ }^{1}$, Angelia Sulistiwaty Sugianto ${ }^{2}$ \\ ${ }^{1}$ Graduate Lecturer of Persada Indonesia University, YAI - Jakarta, \\ No Hp. 081511617896. Email: ilonaoisina@yahoo.com \\ ${ }^{2}$ Marketing Staff of Bunda Mulia University, Jakarta, \\ No Hp 081280947560. Email: angelia.ciacha@gmail.com
}

\begin{abstract}
Tourism nowadays is entering a new era. Recent years, tourism is the best bussiness in many countries. This research discusses about The branding strategy analyzed using STP theory (Segmentation, Targeting and Positioning) on Wonderful Indonesia campaign. This campaign is the Leading Campaign for Indonesia tourism in International level. Data collection was obtained from observation, books and interview. The result obtained from STP analysis theory can be used to develop branding strategy in wonderful indonesia campaign. The innovation is founded in tourism and development of tourism product like village and religion tourism can be applied in Indonesia tourism. Within positive development in this campaign, Indonesia is expected able to compete with the other ASEAN countries while AFTA and MEA policy applied in 2015.
\end{abstract}

Keywords: Wonderful Indonesia, Campaign, Persuasive Message.

\begin{abstract}
Abstrak
Dunia pariwisata memasuki era baru. Beberapa tahun belakangan ini pariwisata merupakan primadona bisnis di berbagai negara. Penelitian ini bertujuan menganalisis strategi branding dengan menggunakan teori STP (Segmentasi, Targeting, dan Positioning) pada kampanye Wonderful Indonesia. Kampanye ini merupakan: Leading Campaing pariwisata Indonesia di kancah pariwisata Internasional. Metode penelitian deskriptif kualitatif dengan pengumpulan data observasi, dokumentasi buku-buku dan wawancara. Hasil penelitian yang diperoleh dari Teori analisis STP dapat membantu proses pengembangan strategi branding pada kampanye Wonderful Indonesia. Adanya Inovasi di bidang pariwisata yang ditemukan serta adanya pengembangan produk pariwisata seperti desa wisata dan wisata agama, bisa di terapkan pada pariwisata di Indonesia. Dengan adanya pengembangan yang positif pada kampanye ini, Indonesia bisa bersaing dengan negara ASEAN lainnya ketika kebijakan AFTA dan MEA tahun 2015.
\end{abstract}

Kata kunci: Wonderful Indonesia, Kampanye, Pesan Persuasif.

\section{Introduction}

Indonesia is an country with archipelago and wide-spread seas, from Sabang to Merauke. Indonesia is growing to be one of traveling destinations, but not entirely exposed well. In 1992 the Indonesian government launched a campaign program to introduce the truly Indonesian tourism to the world. It was named "Visit Indonesia".

One point that should be improved in Indonesian tourism is that promotion.
In favor of gaining tourism potential, the government should take a good strategy. Indonesian government should adopt promotion as a tourism branding strategy. This is one of effective communication and a fast way to increase and expose Indonesia tourism.

The "Visit Indonesia" campaign was aimed to raise public awareness about the beauty of Indonesia nature which spread out from Sabang to Merauke. The 
campaign program has been ongoing since 1992 and changed its name to "Wonderful Indonesia" in 2011 by the Indonesian Minister of Tourism, Mr Jero Wajik; and remain unaltered by the current Minister of Tourism, Mr Arif Yahya.

Wonderful Indonesia divides its market segmentation into two parts, one branding namely "Wonderful Indonesia" is dedicated to international markets and "Pesona Indonesia" to the domestic market. The purpose of this campaign is merely based on its market segmentation. The campaign carried by Indonesia's Ministry of Tourism was aiming to promote natural and cultural richness in Indonesian tourism.

Wonderful Indonesia campaign will construct identity for nationbranding. Nation branding not only just about an eye-catching campaign logo or great slogan, but also regarding how a nation can describe identity, characteristic and culture throughout branding activity. Indonesia is one of nation that create nation branding campaign called Wonderful Indonesia which has been used since 2011 . Beforehand, Indonesia used Visit Indonesia for nation branding campaign (Claristy \& Trinohandoko, 2016:1).

"Wonderful Indonesia" - now accompanied by "Pesona Indonesia", is Indonesia tourism pledge to the world with strengthening Indonesia in international tourism competition. Words, "wonderful or Pesona" show the message "rich and Wonderful" from any aspects either human, culture, or its nature. All of them is touching and giving new experience.
Tourism branding refers to the three main message that is culture, nature and creative (man made). three of this message means Indonesia nature is the most beautiful in the world such as the sea, beach,mountain, forest and all the variety of flora and fauna from Sabang to Merauke, from Mianggas to Rote. Indonesia also has a variety in culture such as ethnic, language, and customs. Meanwhile creative product (creative-man made) represents Indonesia man power which could create a variety creation, attractiveness, and alluring worldwide attractions.(www.indonesiantourism.com).

"Wonderful Indonesia" and "Pesona Indonesia" branding purpose must be supported as a national brand by all provinces agencies in the tourism industry. In addition to attaching national tourism branding, some tourism parties are expected to support Indonesia tourism through positive press, improvement in travel services, especially health and hygiene, as well as the utilization of e-tourism. those are expected to support target achievement of 12 million tourists by 2015 and the competitiveness of Indonesian tourism rose by TTCI (Travel and Tourism Competitiveness Index) World Economic Forum to rank 30 (Kertajaya, 2014:33).

Wonderful Indonesia and Enchantment Indonesia as a branding of tourism is expected to be supported by all tourism stakeholders in Indonesia including business offices (businesses), and local governments. In Indonesia's tourism development strategy, stakeholders consisting of five main actors, industrial government, academia, community and media (penta-helix), are 
expected to play an active role in promoting Indonesian tourism. All tourism activities both offline and online should be able to put the logo brand Wonderful Indonesia or Pesona Indonesia in it (Priyatmoko, 2016:85).

Developed and developing countries began to rely on tourism as an field of their greatest foreign exchange. In 2010, we learn from Singapore's success netted nine million foreign tourists per year with a branding "Uniquely Singapore". Malaysia has reached more than 24 million foreign tourists per year with "Truly Asia" and Thailand successfully reaching nearly 16 million international tourist through the tagline "Amazing Thailand". India, in spite of a rather aggressive use of "Incredible India", however only able to reach 5.5 million foreign tourists in 2010. India has domestic arrival of which figure reached 705 million.

Indonesia is still dwelling on the figure of 7.5 million foreign tourists. Countries like Singapore-which is essentially a small country with meager resources, could make the country as an attractive tourism country. Singapore government began to build a lot of man-made attractions as a selling point for the country. Compared with Indonesia, we have much more diverse to offer; yet we are still unable to utilize the natural resources due to human resources deficiency. The Indonesian government optimistically declared a target where by the end of 2015 , the Ministry of Tourism will have enticed 12 million global tourists.

Business tourism in Indonesia is in the growing phase. In 2012 Indonesia joined the Trillion Dollar Club, a list of countries that has a gross domestic product in excess of one trillion dollars. As a new member of this club, Indonesia ranked the 15th largest economy in the world. It can be proved that Indonesia has an influence on the global economy (Kertajaya, 2014:55).

In 2012 the number of tourist arrivals reached 8 million people, with the majority of visitors from Singapore, Malaysia, Australia, China and Japan. With the increased number of tourists, Indonesia can take advantage of this opportunity to implement a marketing strategy that is "Turning Tourist to Advocate". This strategy aims to share to friends via social media or mouth to mouth about the experience of tourism in Indonesia. With the tourists becoming advocates, it will help to promote the tourism in Indonesia. If the strategy of "turning tourist to advocate" is successfully implemented, it is advantageous for Indonesia. Within the development of tourism areas in Indonesia, it can help Indonesia as an independent state and gain the legitimate recognition from other countries.

The development of the world community awareness about the "Wonderful Indonesia" campaign requires appropriate strategy and good communication analysis. In this campaign, the government expected good response from tourists. This study identifies the message processing by Imaging Division of the Ministry of Tourism Indonesia to be able to achieve the target of 12 million foreign tourists per year by 2015 . This is covered through Kenneth Burke 
Identification Theory. The theory holds that in the processing of campaign messages, an agent of change should be able to find good position itself to calibrate with the target audience. With so many similarity between the Wonderful Indonesia campaign and foreign tourists, the tourists can perceive positive message delivered in the campaign, so the identification of a persuasive message from Wonderful Indonesia campaign undertaken by the Imaging Division of the Ministry of Tourism Indonesia in achieving the target of 12 million foreign tourists per year in 2015 can be conducted.

The objective of this research is: "The Identification of persuasive messages in Wonderful Indonesia campaign program collated by the Imaging Division of the Ministry of Tourism Indonesia to foreign tourists."

Pace, Peterson and Burnett define persuasion as: "the act of communication that aims to make the audiences adopted the view of communicator on a matter or perform a particular action" (Venus 2009: 30). Johnston on communication persuasion, expressed: "Communication persuasion is a transactional process between two or more people where there is an attempt to construct reality through the exchange of symbolic significance which produce changes in beliefs, attitudes or behavior voluntarily" (Venus 2009:30).

Persuasive communication is closely relevant with the application of the campaign where the audiences are expected to accept the invitations or messages conveyed in the campaign. Therefore, persuasion today is a benchmark in the manufacturing of a campaign message (Venus, 2009:31).

Kenneth Burke's theory of identification, begins with the difference between action and movement. He states that, the action consists of deliberate and purposeful behavior. While the movement is not intended to and does not contain meaning. Objects and animals have a movement, but only human beings have action. Burke argued that humans create symbols to signify something, and then to communicate and often abuse their symbol because of its shortcomings. Burke agreed that the language serves as a "vehicle" for action, because of the basis of social need, it takes people to cooperate with his actions, so that the language can shape behavior. Language, as well as Burke's views, always emotionally charged. There are no words that can be neutral. As a result; behavior, judgment, and our feelings are not visibly variable in the language we use. Language is selective and abstract as well as focusing on certain aspects of reality in its breadth of other aspects. Languages are economic, but also ambiguous. Language can unite or divide us, this paradox is an important role in Burke theory (Morissan, 2014:174).

When the symbol unites individuals into a common understanding, then the actual identification process has taken place. Division or separation may also occur, because the language can lift identification or separation and division. One of the existing identification is the similarity or proximity (consubtantiality). Identification can mean an invitation and an effective delivery or be the end of the 
communication itself. Identification may be consciously or unconsciously, planned or unplanned. According to Burke, there are three interrelated sources of identification. First, the identification of the material (Material Identification), the results of goodness, ownership, and objects; such as having the same car, or share the same taste. Identification idealistic, a result of an idea that is shared along with attitudes, feelings, and values, such as members of political parties. And the last is formal identification sourced from the setting, such as in an organization where many parties are involved (Morissan, 2014:177).

This process occurs through their hierarchy or strata divergence. For example, people tend to identify themselves with those from the higher strata, or considered to be charismatic, influential or idol to imitate. Identification through mystification, is the term used to describe where a role model is so revered because they are considered as perfect and people tend to ignore the possibility of unwanted flaws. Principle of ideal or perfection creates guilt and motivate the parties to identify in order to make them more similar to the charismatic leader (spiritual leaders in religious organizations, successful people who became inspiration, etc.). The divergence in strata creating hierarchy principle which triggers competition, contribute to development of guilty feeling if one cannot afford being the same or similiar to the ideal figure who usually are the politicians who seek to bring the audience closer. Although Burke developed this theory in the mid- 20th century, his ideas precede movements in communication research, particularly in message delivery strategy (Littlejohn, 2009:167).

According to Michael Pfau \& Roxane Parrot, campaigns are inherently persuasive communication activities, so that campaign activities are always attached with persuasive communication activities. Although at the core of campaign activity is contrary to the act of persuasive communication. There are at least four persuasive communication aspects in campaign activities, as follows (Ruslan, 2013:27): (a)The campaign is systematically working to create space in the public mind regarding feedback of certain product, candidates, and idea of specific program for the benefit of the target audience. (b) Campaign progresses through various stages, begin with attracting attention, accelerating the promotion of campaign themes, motivating and encouraging to act as well as the participation of the target audience in doing real activity. (c) The campaign should be able to dramatize the theme of the message or ideas exposed openly and encourage the participation of the target audience to get involved both symbolically and practically to achieve the objectives of the campaign themes. (d) The success or failure of the campaign reputation are determined through cooperation with the mass media to arouse attention, awareness, support and capability to change the behavior or action of the audience.

A campaign will also require a careful and precise design. A campaign planning 
needs 12 steps that can help the effectiveness of a campaign, i.e (Ruslan, 2013:52): (1) Research. No matter what type of activity, research is its center. Depending on what you are doing, different research methods can be applied in each different time. (2)Analysis of the situation. Through the situation analysis you can use SWOT analysis to evaluate the strengths, weaknesses, opportunities and threats of the existing situation.(3) The purpose; the intention is what is expected to be the end result of the campaign activities, and each goal should be: (a) Specific (clear and comprehensive). (b) Measurable (can be measured and evaluated). (c) Achievable (can be managed and accomplished). (d) Realistic (rational with available resources). (e) Time (Measure of the time when these objectives can be achieved). (4) Identifying the public, whom to invited. It is essential to ensure that the message conveyed can be precisely targeted as effectively as possible. (5) Identifying stakeholders; stakeholder analysis can include employees, factories, suppliers, senior executive, investors, and others. (6) Key message. After learning the situation, who is going to ask sharing, then a plan of what you are going to talk about is a necessity. It should be clear, concise and easy to understand. (6) Strategy is the foundation where a tactical program is built upon. It is a theory that can take you from the existing situation to the desired situation. Usually, strategy is a mechanism in which the campaign tactics directed toward the goals. (7) Tactics. Depending on the type of campaign where you are concerned, there are a variety of platforms that can be used such as media relations, lobbying, events, interviews, blogger relations, presentations, consultations newsletters, competitions, websites, conferences, photography and so forth, (8) Period. Once you get the whole idea of the overall strategy you will use, then you need to allocate time to do so. Having a schedule help you to coordinate tactics in a timely manner and also help you become "aware" with a deadline. (9) Budget; the main reason for creating a budget is you can also find out what is within reach and what is not, and also so that you can allocate costs for the particular areas of the campaign. (10) Issues and Crisis Management. Risk is an inevitable part of a campaign, preparing for any possible risk is a crucial thing. (11) Evaluation. Evaluation is a continuous process, especially on the campaign within long period of time. Hence reviewing all specific elements is a compulsory.

One of the purpose of nation branding is tourism awareness. Anholt (Yee, 2009) said in "Anholt Branding Hexagon" (Fan (2006:6) in order to construct nation branding, there shoukd be any representation which contain fanctors and essential element that building image: Geographic, Nature resources, tourism spot, community, race, ethnic, culture, language, economic and politic system, social institution, infrastructure, figure and image.

The first point/element mentions "tourist attraction" indicating that tourism destinations become one part in the implementation of nation branding. Fan (2006:6) then adds by mentioning that there are two reasons why nation branding is done. 
First, is to improve the country's image and increase sales and exports in the presence of country-of-origin effects. Thus, the image is built in such a way that overseas audiences believe that the products produced by the country are reliable. Second, is for place marketing, which is to promote the country (or city in the country) as a tourism and investment destination. (Claristy, 2016: 6).

\section{Research Method}

This study used a qualitative research approach. Bogdan and Taylor in (Moleong, 2008:4) states: "Methods of qualitative research as a research procedure that produces descriptive data in the form of words written or spoken from people and observed behavior.

Mean while (Nasution, 1996:34) adduce if qualitative approach have same goals: 1) Get the especially describe and holistic about all aspect from the research subject. 2) To see the phenomena overall with the context. 3) understanding the meaning. 4) To see the result of research be a speculative.

By Qualitative approach a research could make use of the teories be a theoretical foundation for this research therefore expected the result can be accounted by researcher.

This research is descriptive, the research describes the characteristics/traits of individuals, situations, certain groups as research objects. (Ruslan, 2008:12). According to Sugiyono (2006:236), "Descriptive Research is defined as a formulation of the problem that guides researchers to explore or photograph the social situation to be studied thoroughly, broad and deep."
To analyze this research we used descriptive method with case study. Descriptive method analysis is a research method that make how to illustration about situsional and the recent condition. Descriptive method illustrated and interpreted the object as it is.

Where as the case study method is how it's explained that any aspects an individu, a group, an organization (community), a program or a social situation. The review for a case intensively. According to creswell that said if (1994:12): "case study in which the researcher explores single entity or phenomenon ("the chase") bounden by time and activity a programe, event, process, institution, or social group and collects detail information by using a variety of data collection procedures during a sustain period of time.

The case study method is one of the strategies and methods of qualitative data analysis that emphasizes on the special cases occured on the object of analysis. The case study is an empirical inquiry that investigates phenomenon in the context of real life, when the boundaries between phenomenon and context are implicit, where multi resources evidence are utilized. Inquiry means an analysis. In the case study, the evidence gathered by investigators become vital in analyzing a reality or research problem. Evidence or data for case studies may come from six sources: documents, archive footage, interviews, direct observation, participant observation, and physical devices. (Robert K.Yin, 2013:22). 
Researchers divided the analysis into two units, namely subject and object. The subject of research in this study is the strategy of Imaging Division for of Wonderful Indonesia Campaign, which develop into Indonesia's tourism representative on the global stage. The object of this research is the identification of a persuasive message prepared by the Imaging Division of the Ministry of Tourism Indonesia toward foreign tourists. To support this research, there are several requirements for key informants position: (1) An expert in the Indonesia tourism. (2) A person who profoundly understands about the planning of Indonesia tourism branding message, especially Wonderful Indonesia. (3) A person who works for the Ministry of Tourism in Indonesia. (4) An expert or leader that have a considerable influence on the Wonderful Indonesia campaign

Key informant in this research is Mrs. Budihardjanti, she is Head of Sub Directory for Imaging Strategy of Wonderful Indonesia Campaign. To support this research, there are several requirements for informants: (a) Staff of Imaging Strategy of Wonderful Indonesia Campaign. The chosen staff is Mrs. Komang Ayu, she has been working in the ministry since 2010. She is responsible for assisting Mrs. Budihardjanti in formulating and pursuing a strategy of imaging. (b) Journalist or blogger of Indonesia tourism. The chosen journalist and blogger is Marischka Prudence, a travel blogger who turned out to be official brand ambassador of Wonderful Indonesia campaign.
The process of qualitative data analysis as suggested by Moleong above is very complicated and overlapping in phases. Stages of data reduction to data categorization is an integral process that can be collected in a data reduction. Because in this process, unit rafting and data categorization is already summarized (Moleong, 2008:88).

Method of Data Collecting: Primary Data. This data source can be the respondent or the subject of research, from the results of conducting in-depth interviews and observation. Researchers used in-depth interviews to collect data in research. Researchers also used the snowball sampling, where the key informants and informants were acquired through informants' connection. Secondary Data. In this study, researchers used literature to explore and complement this research.

\section{Result and Discussion}

In regard to the aformentioned background and formulation of the problem, researchers sought information from interviews and observations during the study. This is performed to answer the purpose of this study, which is to determine the identification of the persuasive message from Wonderful Indonesia campaign compiled by Branding Division of Ministry of Tourism in accordance with the goal of achieving 12 million of foreign tourists in 2015. The results are following:

\section{Identification of Persuasive Messages Plan- ning of Branding Division Through The Wonderful Indonesia Campaign}

In this study, it was found that the used identification to design the campaign messages is the ideal identification. 
According to Burkhe, ideal identification is the identification that comes from the ideas, attitudes, feelings and values. With the Wonderful Indonesia campaign program, the Branding Division should feature the campaign messages as attractive as possible so it will attract many tourists to come. Foreign tourists are people around the world who have many different cultures and backgrounds, but in this case the Ministry of Tourism has already assimilated the market so that promotions in marketing communications can have an ultimate purpose; to introduce Indonesian tourism and encourage foreign tourists to visit Indonesia. After the passage of this campaign for 12 years, millions of foreign tourists had come to Indonesia during the holiay and were satisfied with the uniqueness of Indonesia.

Before designing a campaign message, the Branding Division of Ministry of Tourism need to know what products that will be the material during the campaign. Branding Division should know what the Indonesian and the foreign tourists have in common. In accordance with the theory of identification, Burkhe stated that with the identification, there will be resemblance with audiences as a result of positive feedback from the public. This is also supported by a statement from Budihardjanti:

"Indeed, prior to creating the message of this campaign, we have always held a meeting, presenting specific data to see the market demand, our target market is diverse but we should set the campaign message as attractive as possible. Usually we conducted a survey to the field directly so that we can position ourselves as foreigners"
From interviews with key informants Mrs. Budihardjanti, the Indonesian Government has compassed a lot of activities to support the advancement of Indonesian tourism in the eyes of the world. One is conducting a survey to determine the appropriate market segmentation for tourism campaign. To be able to determine the proper persuasive messages, we require an identification of the target audience which is the main focus in this campaign. Therefore Budihardjanti study stated that there are five countries that became the target audience of the Wonderful Indonesia campaign. This is strengthened by the statement from Budihardjanti:

"Currently, yes five countries that I mentioned earlier, that became the target of Indonesian travelers; there are China, Singapore, Malaysia, Japan, and Australia".

From the observations, the researchers obtain accurate statistical data obtained from the Ministry of Tourism newsletter from March 2015 edition.

Table.1 Number of foreign tourists visit by primary market

\begin{tabular}{|c|c|c|c|c|c|}
\hline \multirow{2}{*}{ No. } & \multirow{2}{*}{ PASARUTAMA } & \multicolumn{2}{|c|}{ JAN-FEB } & \multirow{2}{*}{$(+1 / 4$} & \multirow{2}{*}{ SEISIH } \\
\hline & & 2015 & 2014 & & \\
\hline 1 & TIONGKOK & 218.023 & 185,377 & $17.61 \%$ & 32,646 \\
\hline 2 & SINGAPURA & 201,585 & 211,794 & $-4.82 \%$ & $-10,209$ \\
\hline 3 & MALAYSIA & 175,540 & 206,894 & $-15.15 \%$ & $-31,354$ \\
\hline 4 & AUSTRALIA & 169,318 & 154,169 & $9.83 \%$ & 15,149 \\
\hline 5 & JEPANG & 82,666 & 72,837 & $13.49 \%$ & 9,829 \\
\hline 6 & KORSEL & 66.838 & 63,288 & 5.6196 & 3.550 \\
\hline 7 & INDAA & 40,010 & 34,836 & $14.86 \%$ & 5,174 \\
\hline 8 & AS & 34.521 & 35,006 & $-1.39 \%$ & -485 \\
\hline 9 & INGGAIS & 32.922 & 30,220 & $8.94 \%$ & 2,702 \\
\hline 10 & TANWAN & 32352 & 34,783 & $-6.99 \%$ & $-2,431$ \\
\hline 11 & TIM-TENG & 24,826 & 26,186 & $-4.81 \%$ & $-1,260$ \\
\hline 12 & PERANCIS & 23,193 & 21,904 & $5.88 \%$ & 1,289 \\
\hline 13 & BELANDA & 21,893 & 21,356 & $2.61 \%$ & 557 \\
\hline 14 & JERMAN & 20,396 & 21,006 & $-2.90 \%$ & -610 \\
\hline 15 & FILIPINA & 19.267 & 19,715 & $-2,27 \%$ & -448 \\
\hline 16 & HONG KONG & 12.698 & 12.879 & $-1.41 \%$ & -181 \\
\hline 17 & THAILAND & 12,328 & 12,329 & $-0.01 \%$ & -1 \\
\hline \multirow[t]{3}{*}{18} & RUSIA & 12,021 & 20,915 & $-42.52 \%$ & $-8,894$ \\
\hline & PASAALAININYA & 309,195 & 270,271 & $19.40 \%$ & 38.924 \\
\hline & GRAND TOTAL & $1,509.692$ & 1.455 .745 & $3.71 \%$ & 53.947 \\
\hline
\end{tabular}


In accordance with the aforestated data, it can be seen that the Wonderful Indonesia campaign target are country of China, Singapore, Japan, Malaysia, and Australia. Based on the undertaken survey by Branding Division, these five countries are the top-five countries with a high interest on tourism in Indonesia. Evidenced by the many Indonesian cultural-mix with their culture; ranging from food, music, to lifestyle.

Referring to Burkhe, identification of messages prepared for the tourists from the main market could conclude what can bring up similarities and produce the desired feedback. Burke said that instead of accentuating cultural difference with the target audience, we should highlight more similarities so that the audience can positively respond to the conveyed messages. So it can be concluded that the key to effective persuasive communication in this campaign is to emphazie on the resemblance between the culture of Indonesian and the foreign tourists. In response to this, Budihardjanti stated as follows:

"In designing the message in this campaign, we consider a lot of things, ranging from target our campaigns. For example, the Chinese state is currently the largest contributor of foreign tourists. In designing these messages, we know that the Chinese people are very happy with the history associated with their country and they are always joined in large group. Therefore, the promotion is spreaded with the use of Chinese language and promote their empire history that still exists in Indonesia, such as the story of the legendary admiral Cengho in Indonesia"

From Budihardjanti's statement, it can be seen that the Branding Division of Indonesia Ministry of Tourism has already performed what Burkhe said, to emphasize on cultural resemblance and unifying language so it wil develop a sustainable relationship between Indonesian tourism and the Chinese state. Citizens from China today has become one with Indonesian citizens, as evidenced by their existing Peranakan (Indonesian-Chinese half-breed) from Sabang to Merauke.

The Branding Division is aware that any foreign tourists who visit Indonesia have different desires and motives when they visit Indonesia, so the packaging of tourism products messages in Indonesia can be made as vary as possible and then released into the market for reconsideration, which destinations are most interesting for tourists from all over the world.

This is reinforced by Burke Identification Theory which states:

"This theory of message design imagines a more complex scenarios and through that scenario, communicator designs a variety of desired messages that suits the current circumstances" (Morrisan, 2013:180).

In accordance with what Burkhe said, Branding Division of Indonesia Ministry of Tourism is doing a lot of activities whether it's on air or off air related with the promotion of Indonesian tourism. The promotion was very varied but still contains values of Indonesian tourism -which consists of five values that is wonderful food, people, value of money, culture and nature. These values will later be conveyed according to target public. This is supported by the common language. Budihardjanti also provides her perception:

"It is our promotion which contains a lot of content. We customize the message content to suit the target public, for example, if previously it was in China, now it is an example in the country of Japan. The Japanese were very happy with Asian countries in connection with the history of their former glory, and Indonesia was 
one of them. We provide the information that Indonesia is a country that is close to Japanese culture and we also provide information to them that acculturation Japanese culture is immersed in Indonesia."

"Japan and China are small portion of example of persuasive messages procesing compiled by the Ministry of Tourism, Branding Division tried to adjust the content of the message that identifies the audience. Furthermore, the Branding Division also tried to convey the message through digital marketing, one of which is the website. Through the observation, researchers found that the current Indonesia Ministry of Tourism website is already available in various languages, such as Mandarin, English, German, Japanese and Italian.”.

Preparing website in multiple languages is also addressed by Komang Ayu as staff of Branding Division. She said that:

"In digital marketing promotion, we have a website in multiple languages which is dedicated for tourists of each country. This website is managed directly by staff of Indonesian ambassador in the representatives country. The contents also vary; starting from the latest news on Indonesian tourism to the tips and tricks for to holidaying Indonesia"

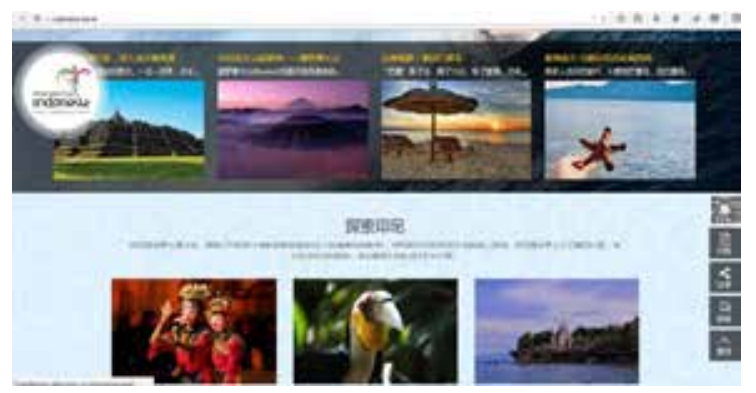

Figure 1 Wonderful Indonesia website in Mandarin

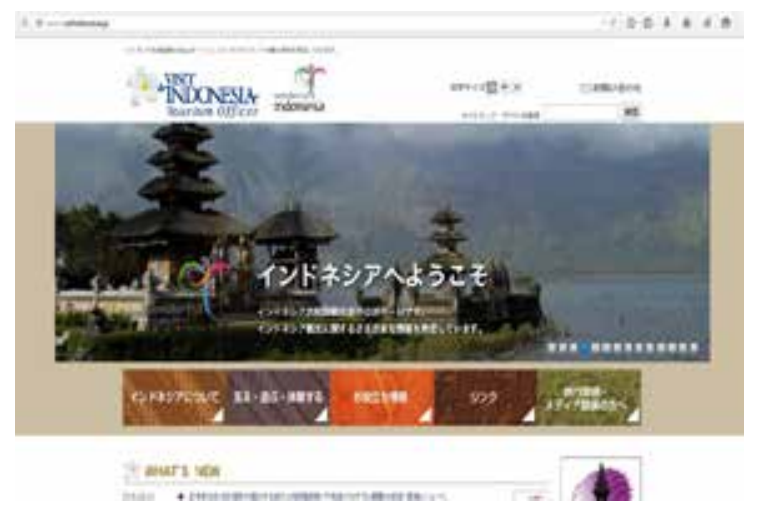

Figure 2 Wonderful Indonesia website in Japanese
In accordance with what Komang Ayu stated that on this website every news and information is written in a daily language that is used by tourists. This website is managed by a assigned Indonesian ambassador staff in the representatives country. This website explains what are the advantages of tourism in Indonesia and the similarities between Indonesia and the market-directed countries.

According to Burke, besides the language, trust can also be an identification that can unite humanity. Branding Dvision of Indonesia Ministry of Tourism saw this as an opportunity that can be used to attract tourists who are looking for spiritual tourism. Indonesia has the Borobudur temple, which is the world's largest Buddhist temple. It is confirmed by the statement from Budihardjanti:

"Indonesia has a lot of potential, if in the past we only had promoted its natural and cultural beauty, this time we will expand into pilgrimage tourism or spiritual travel. Indonesia is the largest Islamic country but at the same time it even has the Borobudur temple which is the world's largest Buddhist temple."

Correspondingly with Budihardjanti, this message will be conveyed to the Asian markets that practice Buddhism. Given this similarity, tourists from Asian countries market will be interested to come to carry out spiritual tourism in Indonesia. It can be imagined how many millions of Buddhists residing in Asia that will go for spiritual travel to Indonesia.

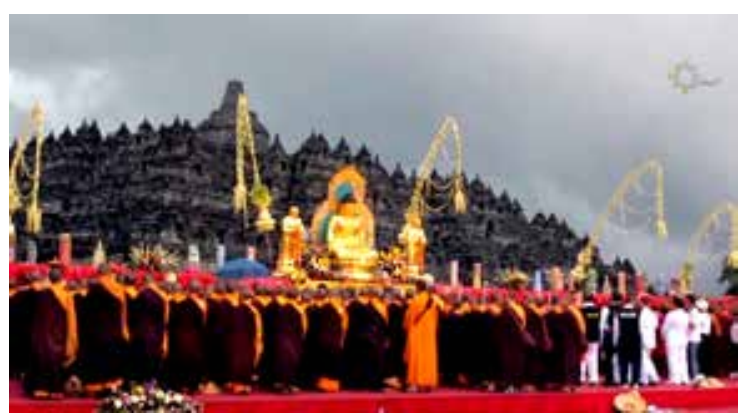

Figure 3 Vesak Celebration at Borobudur 
In addition to trust, according to Burkhe, identification process also depends on the likeness of ideas that form the audience. Therefore, Indonesia is following the market trend in which everyone is now correlated with gadgets and social media. Looking at the phenomenon, the Branding Division of Indonesia Ministry of Tourism begin to create accounts on social media to support the Wonderful Indonesia campaign. This is also confirmed by a statement from Budihardjanti:

"Today, we know social media is very influential in the lives of foreigners, many people are using social media to show their social existence. Therefore, our team has launched a social media account for Indonesian tourism, with contents of natural beauty of Indonesia. We upload a lot of photos and activities and inform details about what we do."

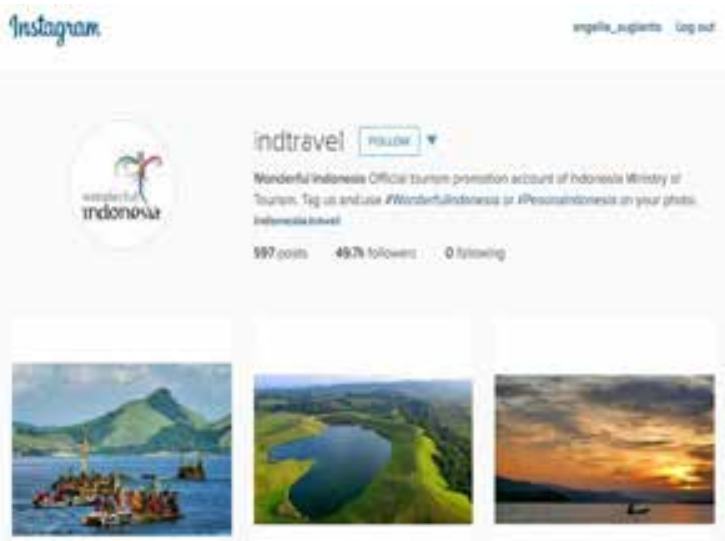

Figure 4 Indonesia Instagram Account

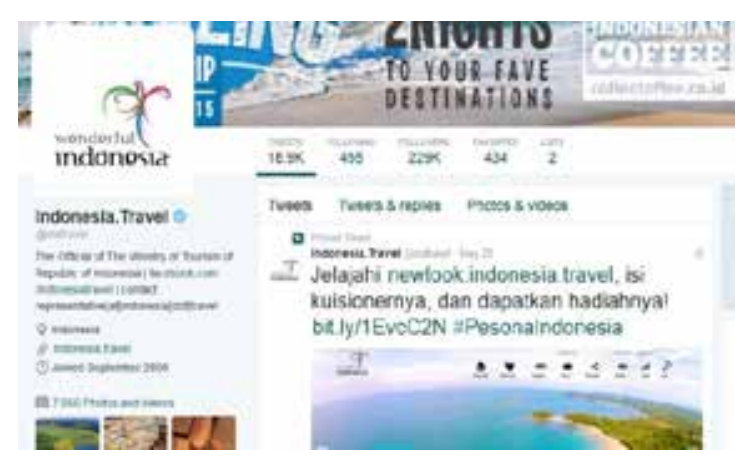

Figure 5 Wonderful Indonesia Twitter Account
In accordance with what Budihardjanti adressed, Branding Division is very active in following the development of digital marketing, because the market target - ie tourists at this time, are very fond of social media. To convey the message properly, social media accounts are beneficial to deliver persuasive message toward foreign tourists to visit Indonesia. It is also supported by Komang Ayu:

"Well, today we focus on the digital marketing, we accelerate branding through digital marketing. Low cost and affordable, social media is an alternative work agenda to improve branding and invite tourists to come to Indonesia."

As identically described by Budihardjanti and Komang Ayu, Indonesia is striving to follow the market trend. Digital marketing is currently the main activities performed by Ministry of Tourism beneficial to promote tourism in Indonesia.

"Guilt" In Identification of Persuasive Messages Designing by Branding Division of Indonesia Ministry of Tourism

\section{"Guilt" in Burkhe's theory of identification} is a negative situation that prevents message delivery to the audience. Messages which are currently being designed will encompass Indonesian tourism products, but will Indonesia be able to accommodate the desires of the foreign tourists? This is taken seriously by our informant stating that:

"Currently, Indonesia is still in the stage of developing tourism, although Indonesia has not fully become the target of foreign tourists holidaying, but with the natural resources in Indonesia, I think Indonesia could become a country that can fulfill the desire for foreign tourists holidaying" (Budihardjanti)

"So if we see, we have the potential and competitiveness, from nature and culture, because there are approximately 300 ethnicities in Indonesia, it is considered as a strength. Well the challenge 
would be $3 \mathrm{~A}$; attraction, accessibility, and amenities. If we want to go to Raja Ampat, for instance, we need 9 hours to get there. It proves that access to the area is very difficult to reach and also requires costly transportation. We have the potential but at the same time we are lacking of the transportation mode. Speaking competitiveness will also mean concerning the price of competitiveness."(Komang Ayu)

From the responses given by Budihardjanti and Komang Ayu, researchers saw that Indonesia has been able to satisfy the foreign tourists' need of vacation, but the infrastructure is not well-established yet, we have learn from closest countries of which infrastructures are solid.

In Burke's Theory of Identification, this is referred as "guilt" that can lead to negative situations between communicators with he communicants. It hinders the process of delivering a message to the tourists. Indonesia's negative sides must be neutralized as favorable as possible, so that the foreign tourists can accept the persuasive messages.

This is also reinforced by a statement from Marischka Prudence, a travel blogger from Indonesia, where she stated that:

"Since a long time ago Indonesia has become one of exotic destinations, especially for people from European countries and even many popular locations internationally. The early discoverer were usually foreigners. A spot surfing in Mentawai, G-Land, or Wamena usually get a lot of visitors especially when the festival Baliem is held. Accommodating desire? depending on what kind of desire, each nation has the character (and of course the desire) that is different, so the suitable packaging and destination in Indonesia may differ from one country to another."(Marischka Prudence).

From the responses given by Budihardjanti, Komang Ayu, and Marischka Prudence, researchers concluded that Indonesia is a country with huge potential, because our natural resources are nowhere near inferior to other countries. We have hundreds of ethnicities and regional languages, which makes Indonesia is rich in culture and ready to compete with tourism from other countries. However, due to the negative side of Indonesian tourism, it can dissipate the desire of tourists to take a holiday in Indonesia. The existing guilt can hinder the process of identifying existing message. The infrastructure includes the readiness of facilities and transportation, and tourist location information is still rarely found in tourist locations in Indonesia. In response to this, Budihardjanti to respond:

"The problem of infrastructure is a typical problem in Indonesia. There are so many complaints that we received on this issue, we are still very limited in budget and improvement of infrastructure requires quite a long time, therefore now our campaign is more directed at tourism branding positioning."

Indonesia has some flaws or "guilt". These deficiencies include the infrastructure and branding of our tourism. When researchers asked about the campaign logo "Wonderful Indonesia" randomly in the Kota Tua area, three foreign tourists (Christian, Yura and Julien) did not know the logo of "Wonderful Indonesia". In his Theory of Identification Burke said that the symbols are important in the identification, symbols in this case is the branding logo of Wonderful Indonesia, which ill represent Indonesia's image in the eyes of the world. Concerning this issue, Budihardjanti stated:

"Today the logo has been updated, if the previous one was using website information below, now it has ben removed. The time when creating that logo of Wonderful Indonesia we want society can easily recall the campaign of our national tourism, but somehow the evidence still shows that it's dif- 
ficult to raise brand awareness of this campaign in the community. Other countries like India has a campaign jargon "Incredble India". Every year in Berlin they manage to maintain a very good branding consistency. Year to year they have a powerful concept that is easy to remember, from logo to color in the highlight. I still hope that in the future Indonesia could be consistent in its branding development, avoiding a constantly changing campaign because it would be difficult to remember for the tourists. Deliberately we came up with a simple jargon; "wonderful" but still it's difficult to embed this campaign in society."

From the statement given by Budihardjanti, Wonderful Indonesia logo does requires branding affirmation. The message conveyed in the logo Wonderful Indonesia is Unity In Diversity, it is visible from the colors and figure of an eagle in the logo. Affirmation of this logo should be done continuously so that the tourists can remember branding of tourism in Indonesia.

Furthermore, the Branding Division of Indonesia Ministry of Tourism is currently overcoming the threat or the negative reviews on tourism in Indonesia. There are some reviews given by travel bloggers from other countries about the bad side of tourism in Indonesia. On this Marischka Prudence provides responses:

"Speaking of negative reviews on $\mathrm{t} h \mathrm{e}$ internet, of course it is everyone's right to do so, depending on one's intention to give a feedback. Therefore, I as a citizen of Indonesia have an obligation to counter balance the negative feedback by writing good reviews about Indonesian tourism."

In response to this Budihardjanti and Komang Ayu provides responses:

"This is actually a duty for our division, even though we design a possibly best design and strategy, those negative reviews regarding Indonesia woud still emerge. Not only on tourism but also on Indonesia restless political circumstances. We would try our best to create a positive image for tourism in Indonesia." (Budihardjanti)
"This case is indeed often encountered by our division. This is our challenge as branding division. We will try the best possible to rectify bad responses by showing a good service when they go for a vacation here, so that such negative feedback can be diminished "(Komang Ayu).

Even though Indonesia is currently facing a lot of "Guilt", Bukhe said that "guilt" is inevitable in the process of identification, but agent of change must emphasize on similarities with the target audience than the "guilt" that exists. (Morrisan, 2013:176). Therefore the Branding Division of Indoneisa Ministry of Tourism can be more focused on the positive side of Indonesia compared to the negative side.

\section{Consubstantiality In Designing of Wonderful Indonesia Campaign Messages}

According to Burke, consubstantiality is one-direction identification developed between people. The greater the degree of similarity of humans, the greater significance of identification will be, and therefore can improve understanding. (Morrisan, 2013:176). Branding Division of Indonesia Ministry of Tourism must successfully create consubstantiality between Wonderful Indonesia campaign with foreign tourists to build a closeness to persuade foreign tourists to visit Indonesia. To obtain consubstantialty, Branding Division of Indonesia Ministry of Tourism plunge into the field in the event of a travel event in the destination country in order to create a direct interaction with the tourists. These events are conducted to achieve the target 
to reach 12 million of foreign tourists by the year 2015. To reach out to more foreign tourists, Indonesia Ministry of Tourism has attended several Tour and Travel Fair in foreign countries many times; one of them that is ITB Berlin in the German state, the World Expo in Milano and Cosmos Expo in South Korea. In each expo followed by Indonesia, Indonesia's booth is designed in accordance with the theme and the message you want conveyed by Ministry of Tourism to participants or visitors who attended the Expo. It is also supported by a statement from Budihardjanti:

"Yes of course, one of the largest is the ITB exhibition in Berlin, Germany. During the expo travel abroad, we always adapt any existing messages in such a way in order to develop an understanding between foreign tourists with Indonesia tourism. At that time we held an expo in Abudabhi, all printed material and videos all use Arabic and we were emphasizing on the similarity of belief between Indonesia and Saudi Arabia. So that the SPG and usher were required to wear the veil and dress modestly and use a foreign language."

"To my knowledge, every year we are sure to follow foreign expo, this is done so that the tourists can interact directly with our ushers and can inquire directly about holiday to Indonesia. At the expo we emphasize the direct interaction between visitors and our ushers."(Komang Ayu).

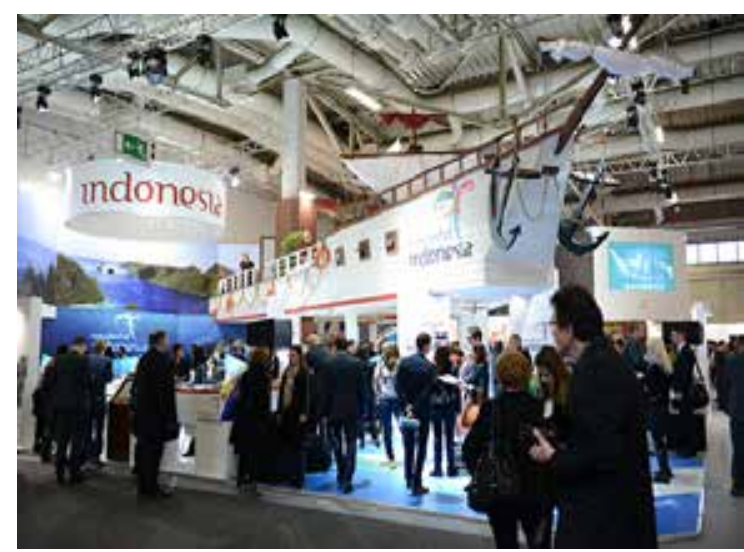

Figure 6 Wonderful Indonesia Pavilion at ITB Berlin Jerman
In accordance with what Budihardjanti and Komang Ayu said, in the expo the tourists can interact directly with the usher who knows the ins and outs of tourism in Indonesia. Burke said that to create consubstantiality, there should the similarity of meaning and language to establish mutual understanding between the communicator and the communicant. Therefore, every usher and the pavilion in the expo is obligated to use the international language and the native language of the host country.

In addition to promoting tourism in Indonesia, branding division also put forward other values contained in the Wonderful Indonesia. Budihardjanti mentioned that:

"Talk about value when the expo, we promote which are becoming consumer insight per country. For example if in Europe or America, we further highlight the value of such wonderful nature, culture, and value of money. Tourists from these countries visiting Indonesia because they want to run a business. That is why we put forward the value of money as well in our pavilion. "

"Usually, before choosing a place for the expo, we will conduct a survey and meeting. How in this expo, Indonesia has unique selling points for the visitors. Usually with different countries, the liking is is also different." (Komang Ayu)

Quoted from Ministry of Tourism newsletter in April 2015 edition, the Branding Division for Wonderful Indonesia campaign already has some of consumer insight (interests) of the following destinations:

a. Singapore

(Discoverers and Cosmopolitant).

b. Saudi Arabia

(Style Hounds, Habituals, Cosmopolitants).

c. Korea Selatan

(Followers, Habituals, Traditionals).

d. Australia

(Functionals and Discoverers).

e. Amerika Serikat (Discoverers, Cosmopolitants and Functionals). 
According to Burke, if you want to improve the consubstantiality then you must improve the identification with target audiences. Therefore, the Branding Division of Indonesia Ministry of Tourism already categorize what is the interest of every country, so that when the message was thrown to the targeted audiences, positive feedback can occur. Consubstantiality not likely to occur if the identification is not the in accordance as target audiences. With so many similarities that appear in Wonderful Indonesia campaign messages with interest of the target countries, there will be an effective communication between communicators with communicant.

Additionally, consubstantiality can be created by using a memorable tagline. This tagline is a form of short message to convey to the tourists. Ministry of Tourism created the tagline "Unity In Diversity" as a Wonderful Indonesia campaign tagline. We should know whether our tagline become the top of mind among the world community when they hear the word Indonesia. According to Budihardjanti as Head of Sub Directory for Imaging Strategy of Wonderful Indonesia Campaign:

"Through this tourism campaign, I want the tourists to see Indonesia as captivating and rich with its natural beauty, with all its diversity yet united as one"

"I hope that our division's hard work to introduce Indonesia can be paid off with an increase in the number of foreign tourists visit to Indonesia. With our tagline of "Unity in Diversity", we want them to know that Indonesia is a country that is unique compared to other countries "(Komang Ayu)

"Although I am not directly involved in the process of manufacturing the tagline, I believe that the tagline can show that Indonesia is a versatile country that can provide the needs of the tourists. I believe Indonesia can show diversity as an attraction for tourists to come and see how "Wow" Indonesian is" (Marisckha Prudence)

With the designed messages it is expected that tourists can understand the same message; to come and visit Indonesia. Branding Division as the main agent of change in this campaign also requires the help from the other stakeholders, this division requires people who will contribute to introduce Indonesian tourism to the world. People who will contribute in this regard are the people who participate and support the campaign of Wonderful Indonesia. These people consist of Indonesian society, journalists/media to brand ambassadors chosen directly by an institution to represent the uniqueness of Indonesian tourism.

Through the tourism campaign conducted by the imaging division is expected to increase the visit of foreign tourists who come to Indonesia, but also through various messages of tourism campaigns that continue to be done will introduce Indonesia's national branding in the eyes of the world. According to research conducted by Claristy and Trihandoko, 2016: 14 says that there are two media campaigns using digital media used by Woderful Indonesia targeting digital native segmentation, or those who often use digital media as one means of information seeking. The use of digital media needs to be improved and developed. The official website for the Wonderful Indonesia campaign looks like it has a changed domain, which can be accessed through www.indonesia.travel or pesona.indonesia.travel. While in an 
official account on other social media, only listed indonesia.travel as a way to access Kemenpar official website.

Branding tourism campaigned through interpersonal communication and various media help the number of tourist visits coming to Indonesia. This is reinforced by the results of research from Maharani, andari, ardianto 2014: 760) said that Brand Positioning Wonderful Indonesia proved influential to motivate foreign tourists to visit Indonesia. Therefore Kemparekraf should increase the dissemination of information on the brand Wonderful Indonesia, so that all tourists recognize the brand Wonderful Indonesia and have a good assessment of Indonesian tourism is described through the brand Wonderful Indonesia, both internally and externally.

Table 2 Research Categorization
After conducting research and relying on interviews and observations results, researchers generated a discussion on the identification of a persuasive message in the campaign of Wonderful Indonesia compiled by the Branding Division of Indonesia Ministry of Tourism. The campaign aims to support the target of 12 million foreign tourists to be achieved by the end of 2015. In this campaign, Branding Division of Indonesia Ministry of Tourism as a team is responsible for designing persuasive communications messages to raise brand awareness of the world community about tourism in Indonesia. Within this section, the researcher will discuss the design of the message and provides a review of its association with the observations and Theory of Identification from Kenneth Burke.

In categorizing which the researchers

\begin{tabular}{lcccc}
\hline \multicolumn{1}{c}{ Analysis Unit } & \multicolumn{4}{c}{ Kenneth Burke's Theory of Identification } \\
\hline \multicolumn{1}{c}{ Interview } & Language & Trust & Ideas & Logo \\
\hline $\begin{array}{l}\text { Budihardjanti } \\
\text { Komang Ayu } \\
\text { Marischka }\end{array}$ & $\mathrm{V}$ & $\mathrm{V}$ & $\mathrm{V}$ & $\mathrm{V}$ \\
& $\mathrm{V}$ & $\mathrm{V}$ & $\mathrm{V}$ & $\mathrm{V}$ \\
& $\mathrm{V}$ & - & $\mathrm{V}$ & $\mathrm{V}$ \\
\hline
\end{tabular}

\section{Observation}

Yuka

Julieen

Charlie

V

$-$

V

V

V

V
V
V

Documentary

News Letter

Online News

Travel Blog

V

V

V

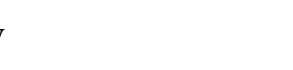

V

ran

-
-
V

V

V

V
V

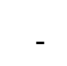

V

\begin{tabular}{lllll}
\hline RESULTS & Consub & Consub & Consub & Guilt \\
\hline
\end{tabular}


explain in the table, it can be seen that Branding Division of Indonesia Ministry of Tourism has appropriately identified a persuasive message for foreign tourists, but there is "guilt" as an obstacle in the given message. Logo of Wonderful Indonesia branding campaign is yet to be recognized by tourists and not yet to be top of mind of the tourists. Although there are "guilt" but consubstantiality is more detectable in the manufacturing process of persuasive message of Wonderful Indonesia campaign.

Burke said that in designing the message, guilt discovery would be inevitable, but an agent of change should create more consubstantiality to the communicant. With what is given by Burke, the Branding Division can create more consubstantiality with foreign tourists with more detail to analyze on what is the interest of tourists.

\section{Conclusion}

In this study, it was found that the use of identification to design the campaign messages is the ideal identification. With the Wonderful Indonesia campaign program, should feature the campaign messages as attractive as possible so it will attract many tourists to come. There is guilt and consubstantiality in the process of identification that affect the response of the tourists in response to the campaign message. Occured guilt is happening due to the lack of awareness of the tourists to the Wonderful Indonesia campaign logo. Consubstantiality is in existing messages such as language, beliefs and ideas. With the identification of a good message, there will be a lot more consubstantiality than guilt, so persuasive messages can be done in improving the foreign tourist arrival target in the coming year.

It is expected that citizen, the related ministries, and other parties to be able to support the Ministry of Tourism to make the tourism campaign program successful. Without the support of stakeholders, Wonderful Indonesia campaign can not run. Practitioners of tourism in Indonesia are expected to help flourishing ideas and creativity in developing regions throughout Indonesia. Infrastructure development in Indonesia also needs support from various parties, so that existing tourism will be able to innovate.

\section{References}

Claristy, Tri CH Trihandoko (2006). Wondferful Indonesia Campaign as Nation Branding Indonesia. (Optimization of campaign media used). Lib.ui.ac.id.FIB UI.

Creswell Jhon W (1994). Research Design Qualitative and Quantitative Approach. Sage Publications.

Fan, Y. (2006) "Nation branding: what is being branded?" Journal of Vacation Marketing Vol 12 No.1. 2006: 5-14.

Gusti Indriasih and Syatri Harto (2016). Indonesian diplomacy in improving Indonesia's international tourism in 20112015. JON FISIP Vol 3 No. 1 2016:1-15.

Kartajaya Hermawan, Sapta Nirwandan (2013). Tourism Marketing 3.0. Jakarta: Gramedia Pustaka Utama.

Littlejohn Stephen W, Karem A Foss (2012). Communication Theory. Jakarta: Salemba Humanika.

Maharani Conny, Rini Andari, Tomy Andrianto (2014). The Influence Of Brand Positioning Wonderful Indonesia To The Decision Of Tourist Tourists To Visit To Indonesia. Tourism and Hospitality Essentials (THE) Journal, Vol.IV No.1, 2014:741-758. 
Moleong Lexy J (2008). Qualitative Research Method. Bandung: Remaja Rosdakarya Offset.

Mulyana Dedy (2002). Qualitative Research Method, New paradigm the science of communication and social science other. Bandung: Remadja Rosdakarya.

Morissan (2014). Individuals and Mass Communication Theory. Jakarta: Kencana Prenadamedia Group.

Nasution S (1996). Qualitative Naturalistic Research Method. Bandung: Tarsito.

Priyatmoko Rakhman, 2016. The Level of Pramuwisata Awareness Against Branding Wonderful Indonesia and Indonesia Characteristics: Tourism Marketing Destination Strategy. Journal of Destination Tourism Indonesia Vol. 1 No. June 1, 2016: 83-102.

Ritonga Jamiluddin M (2005) Tipologi Persuasif Message. Jakarta: Indeks
Ruslan Rosady (2013). Tips and Strategies for Public Relations Campaign. Jakarta: Rajawali Pers

(2008). Public Relations and Communications Research Methods. Jakarta: Rajawali Pers.

Sugiyono (2007). Qualitative and Quantitative Research Methods and R\&D. Bandung: Alfabeta.

Sukardi (2004). Education Research Method: Competend and Practice other. Jakarta: Bumi Aksara/

Venus Antar (2007). Campaign Management. Bandung: Simbiosa Rekatama Media.

Yee, F. Woo. (2009). "Nation branding: A case study of Singapore”. UNLV Theses/ Dissertations / Professional Papers / Capstones. Paper 712.

Yin K. Robert (2013). Case Study of Design and Methods. Jakarta: Rajawali Grafindo Persada.

Website: www.indonesiantourism.com 